\title{
A Narrative Inquiry of an Indonesian Prospective Teacher's Teaching Experiences: Probing Language Teaching Awareness
}

\author{
Zehan Agustia Ainussamsi ${ }^{1}$, Arini Nurul Hidayati ${ }^{2}$, Dede Pertamana ${ }^{3}$, Fuad \\ Abdullah4. \\ DOI: $10.35445 /$ alishlah.v13i3.842
}

\section{Article Info}

Keywords:

Language teaching awareness;

Pre-service teachers;

Narrative Inquiry

Kata kunci:

Kesadaran pengajaran

bahasa;

Guru praktikan;

Pencarian naratif

\section{Abstract}

This narrative inquiry explores the development of language teaching awareness experienced by a prospective teacher during teaching practicum. In this respect, the study provided insight for student-teachers to better understand their language teaching practice under certain kinds of circumstances. The participant of this study was a student-teacher majoring in English Education Department at Siliwangi University, Indonesia. They had already conducted a teaching practice in one junior high school in Tasikmalaya, West Java, within two months of teaching. The collected data from personal diaries written during teaching, semi-structured interviews, and open-ended questionnaires were being processed qualitatively. The findings reported four primary themes emerging throughout the scrutiny of the development in language teaching awareness, namely (1) the dynamic feeling towards the language teaching practice, (2) the adaptability towards the language teaching activities in certain kinds of circumstance, (3) the ability to adjust with diverse teaching circumstances, (4) realization of the pedagogical implication of teaching beliefs and practices. Briefly stated, language teaching awareness explored through self-awareness can promote self-reflection, self-regulation, and self-evaluation.

\section{Abstrak}

Penelitian ini bertujuan untuk mengeksplorasi perkembangan kesadaran pengajaran bahasa dari seorang guru praktikan selama melakukan praktik mengajar. Penelitian ini akan memberikan wawasan bagi para siswa-guru untuk memiliki pemahaman yang lebih baik tentang praktik pengajaran bahasa mereka dalam situasi tertentu. Partisipan penelitian ini adalah seorang mahasiswi jurusan Pendidikan Bahasa Inggris di salah satu Perguruan Tinggi di Indonesia yang sudah pernah melakukan praktik mengajar di salah satu SMP di Tasikmalaya, Jawa Barat, dalam kurun waktu 2 bulan mengajar. Data yang dikumpulkan berupa buku harian pribadi yang ditulis selama masa pengajaran, wawancara semi-terstruktur dan kuesioner terbuka diproses secara kualitatif. Hasil penelitian menunjukkan bahwa ada empat kategori utama perkembangan kesadaran pengajaran bahasa: (1) perasaan dinamis terhadap kegiatan praktik pengajaran bahasa, (2) kemampuan beradaptasi terhadap kegiatan pengajaran bahasa dalam situasi tertentu, (3) kemampuan untuk menyesuaikan dengan keadaan pengajaran yang beragam, (4) realisasi implikasi pedagogis dari keyakinan dan praktik pengajaran. Singkat kata, kesadaran pengajaran bahasa

\footnotetext{
1 Universitas Siliwangi, Tasikmalaya, Indonesia

Email: agustiazehan@gmail.com

${ }^{1}$ Universitas Siliwangi Tasikmalaya, Indonesia

Email: arininurul@unsil.ac.id

${ }^{1}$ Universitas Siliwangi, Tasikmalaya, Indonesia

Email: agustiazehan@gmail.com

${ }^{1}$ Universitas Siliwangi, Tasikmalaya, Indonesia

Email: agustiazehan@gmail.com
} 
yang dieksplorasi melalui kesadaran diri dapat mendorong refleksi diri, pengaturan diri dan evaluasi diri.

\section{INTRODUCTION}

Language teaching awareness was initially proposed in 1999 by Gebhard and Oprandy and defined as a concept to explore the teaching beliefs and practices (Gebhard and Oprandy, 1999; Sifakis, 2019; McNeil, 2020; Gashi, 2021; Beaudrie, Amezcua, \& Loza, 2021). These provide many approaches that could lead the language teachers both in service and pre-service to discover a classroom life into a different perspective. This concept is intended to bring the language teacher to go beyond the usual way of looking to have opportunities to become aware of new things in a very familiar place, that is a classroom. Language teaching awareness aims to promote everyday language teaching into a meaningful discovery for better teaching pedagogy. Furthermore, in this concept, Gebhard and Oprandy (1999) also illustrate how to reach awareness on language teaching itself with self-awareness as the core of the concept. Gebhard and Oprandy (1999) illustrate the linkages between self-awareness, language teaching, and exploratory process as the circle which the self (teacher) awareness as the first circles, and it is followed by the next circles that are language teaching beliefs and practice, and it gets bigger and bigger circle as depicted in figure 1.1.

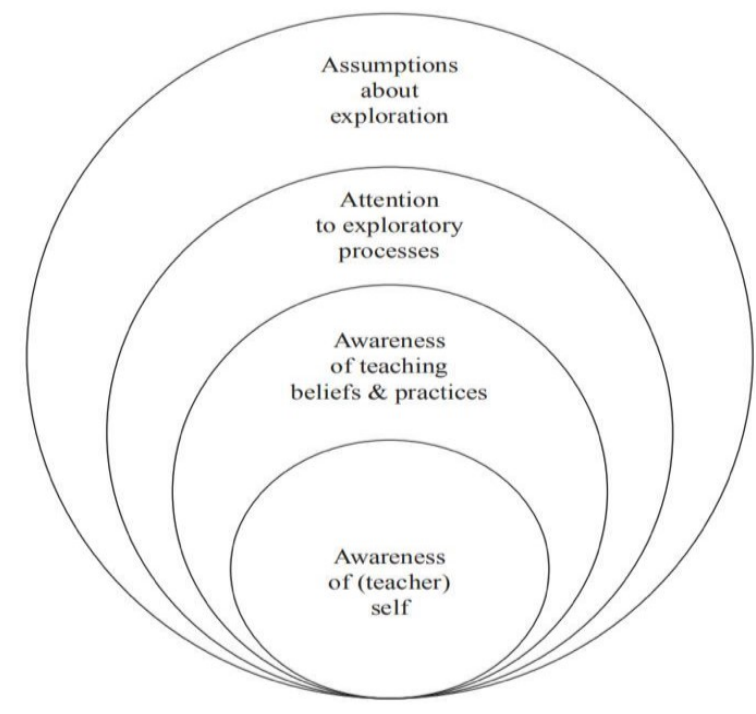

Figure 1. the concept of language teaching awareness (Gebhard \& Oprandy 1999)

From that concept, teachers are expected to learn how language is deployed in a particular context, to a particular interactant, and for a particular purpose. This influences the language teaching practices and beliefs until it comes to the exploratory process and assumption to be reflected by the self (teacher). Self-awareness theory was first proposed by Duval and Robert Wicklund (1972), who argued that, at a given moment, people could focus attention on the self or the external environment. When self-focused, there is a comparison between the self with standards of correctness that specify how the self ought to think, feel, and behave (Sifakis, 2019; McNeil, 2020; Beaudrie, Amezcua, \& Loza, 2021). The process of comparing the self with standards. Contextually speaking, a standard refers to a manifestation of mentality related to behavioural improvements (Duval \& Wicklund, 1972, Sifakis, 2019; Ozonur, 2021; Marwa, Cahyono, Latief, \& Prayogo, 2021). Self-awareness is thus a major mechanism of self-control.

This study applied Gebhard and Oprandy's (1999) approach to language teaching awareness exploration that covers several points such as teaching management, language attitude, and behavior (Abdullah, 2018) towards the language teaching, the indicators, and assumptions of 
A Narrative Inquiry of an Indonesian Prospective Teacher's Teaching Experiences: Probing Language Teaching Awareness , Al- Ishlah: Jurnal Pendidikan, 2021, vol. 13 (3), Pages 2114-2131

Zehan Agustia Ainussamsi, Arini Nurul Hidayati, Dede Pertamana, Fuad Abdullah

the approach are: (1) taking responsibility for our teaching: this approach means, the desire of the exploration and how the draft is going to be modified must come within the explorer. Therefore the authority is fully handed to the explorer, for instances the authority of teaching, what is going to be done about the language teaching itself and how it is going to be reflected, (2)the need for others: the discussion with other is needed to reflect the language teaching whether it is with friend, supervisor or student, (3) description over prescription: any kind of prescriptions must be avoided, rather the explorations have to remain original and explored naturally with the flow of whatever comes to the mind, (4))Non-judgmental stance: the judgment how language teaching is being done needs to be avoided, or how many things achieved or how good the teaching is, for instance 'I'm really bad at grammar' or 'good job, I'm so good at it' so that after the teaching progress could be seen clearly, (5)Attention to language and behaviour: the explorer needs to put the value towards the language behaviour, such as how the language is used in everyday teachings towards the student, how to make the student understand about what is being talked about, also about the vagueness of the language used, (6)avenues to awareness through exploration: including problem solving, seeing what happens, seeing what is by contrasting what is done with what it is thought it is done, or considering what it is believed in light of what is done, and clarifying the feelings, (7)Personal connection to teaching: the comparison between what sort of teacher I am and what I am actually, (8)attention to process and a beginner's mind what is attempted to be explored and how it is going to be explored needs to be well understood. Furthermore, a beginner's mind here is when the exploration is carried out it is needed to begin the "conversations, observations, conferences, and other teacher education activities without preconceived ideas about what it should be going on in the classroom" (Gebhard \& Oprandy, 1999, p.17). In this study, when the assumptions of language teaching are reflected through everyday writing, the development of language teaching awareness could be reviewed by analyzing and comparing what it is done and what it is thought it is done, by seeing what is believed and what is felt. Those indicators are reviewed per week from the dairy so the development of language teaching awareness can be detected.

When it comes to the field of education, shreds of evidence showed by the study suggested that self-awareness has a significant role, especially in the context of teaching-learning activity. Farrell (2013) pointed out that self-awareness is the component that was written the most during journal writing, which influences teacher behaviour construction. In addition, when it comes to the learner's side, Flavian (2016) argued that self-awareness plays an essential role in one's learning development and makes one have the ability as an independent learner. Even in 1991, Gebhard and Oprandy proposed the guidelines for a teacher to evaluate teaching and explore their awareness in teaching, because "increasing awareness makes teachers curious to explore further, leading again to fresh insights and new questions to explore" (Gebhard \& Oprandy, 1991; Marwa, Cahyono, Latief, \& Prayogo, 2021; Boonsuk, Ambele, \& McKinley, 2021). The previous studies have shown us that self-awareness has a significant role in any field either in psychology or education. In the same year, 1991, Mitina mentioned that self-awareness is important to shape professionalism in teaching, which is self-awareness itself; there is faith in a teacher's mission, pride in his profession, and dignity.

Focusing attention on the self could lead to self-evaluation and thus could lead to better action. When one can understand what they think about, talk about and feel about thus it would give them a better insight into what they ought to do and make them more focused on what they do. With that in mind, when the participant started to conduct her language teaching practicum, she began to think that self-awareness might be helpful to cope with this new experience writing a personal diary as what she used to do during her college life since she also acknowledged that teaching in a real-life school situation is not always as easy as it looks like especially when it comes to relating the theory which has been learned in the classroom into practice. Foncha, Abongdia, \& 
Adu (2015) argued that "almost 55 per cent of the student teachers come to realize at the end of their service that their teaching practice failed to give them the opportunities to engage in theory and practice because these teachers were overwhelmed by the realities of the classrooms" (p.128). According to the concept of language teaching awareness (Gebhard \& Oprandy, 1999; Boonsuk, Ambele, \& McKinley, 2021), there are several ways to gain awareness of language teaching is through daily writings. This is in line with Davis \& Brock (1975), who proposed that first-person singular pronouns use in written documents reflects increased self-awareness because pronouns such as 'me', 'my self', and 'mine' indicate that the person is thinking about the self (Boonsuk, Ambele, \& McKinley, 2021).

On the other hand, the study of self-awareness also becomes a controversial discussion. One controversy, reviewed by Paul Silvia and Guido Gendolla (2001), is whether self-awareness enables accurate judgments of the self. However, when it comes to the teaching practice which has been seen as a challenging activity by the student-teacher either practically or psychologically, the theory of self-awareness is such an interesting view to discuss. Pieterse et al. (2013) proposed that "self-awareness has been considered to be a critical ingredient for effective counselling and psychotherapy" (p.190). Considering the phenomenon mentioned and many investigations, it could be perceived that the stressfulness during teaching practice somehow could be cured by selfawareness as the counsel for self-control. Furthermore, another study also showed that people with high self-awareness tend to have a better self-focus to foster perspective-taking. Thus, egocentrism is reduced under the critical condition study (Scaffidi Abbate, Boca, \& Gendolla, 2016). This study, of course, is a good invention, especially for a student-teacher who must guide their students in many kinds of perspectives such as emotions, mental, academics, and ethics which needs high patience and low egocentrism.

The results of previous studies have become evidence that are writing a personal journal is one of the ways to raise self-awareness. Furthermore, in the field of language teaching, there was a study about self-awareness and daily writing by Farrell (2013) which indicates that "writing has a built-in mechanism that facilitates reflection by allowing time for teachers to organize their thoughts so that they can consciously explore and analyze their practice in a more organized fashion than they would normally do" (p.470). Therefore, in this study writing a journal after teaching is then a fruitful approach to be used as a tool to explore the awareness of language teaching that the participant would like to gain. Moreover, Richardson \& Shupe (2003) suggested that "If teachers make conscious, on-going efforts to increase their self-awareness, they will likely enhance their effectiveness and their job satisfaction". This is in line with Gebhard and Oprandy (1999), who argued that increasing awareness causes teachers to explore further, leading again to fresh insights and new questions to explore. Thus, the main objective of this study is to explore the development of language teaching awareness during the period of teaching practicum so that the readers get a better understanding of their language teaching under certain kinds of circumstances.

\section{METHOD}

Narrative inquiry was deployed to unravel the development of language teaching awareness experienced by a prospective teacher during teaching practicum. Narrative inquiry refers to a methodology in which stories are implicated as data or as a means of presenting findings (Barkhuizen et al., 2014). Polkinghorne (1988) also contends narrative inquiry is a way of understanding the human experience through stories that, in turn, help us better understand the human phenomena and human existence (cited in Kim, 2015; Lewis, 2021). Indeed, narrative inquiry endeavours to understand how people think through events, what they value, and what meaning they derive from their experiences (Riley \& Hawe, 2005; Sonday, Ramugondo, \& Kathard, 2020). 
A Narrative Inquiry of an Indonesian Prospective Teacher's Teaching Experiences: Probing Language Teaching Awareness , Al- Ishlah: Jurnal Pendidikan, 2021, vol. 13 (3), Pages 2114-2131

Zehan Agustia Ainussamsi, Arini Nurul Hidayati, Dede Pertamana, Fuad Abdullah

\section{Setting and participant}

The study took place at a junior high school in Tasikmalaya, West Java. During the 2month periods of teaching practicum. The teaching practicum started on August 26, 2019, until November 2, 2019. The participant in this study is an undergraduate student of the English Education Department of Siliwangi University, West Java, Indonesia. She had conducted a teaching practicum. To maintain her privacy, a pseudonym (Tia) was deployed to address her in this inquiry. Tia was a 21-year-old student-teacher possessing a high intelligence with a GPA of 3.94/4.00. Her experiences in gaining self-awareness through dairy writing while she was studying in the English Education department somehow helped her academically. To strengthen the data, there were 31 other participants, one supervisor whom she had been supervised by to be interviewed and 30 students of junior high school whom she had taught to fill the questionnaires.

\section{Data collection techniques \\ 1. Participants'writing journal}

The main data was collected from a participant's documented personal diary written every day after teaching during a two-month teaching practicum period. She wrote what happened in the class and described what she felt and thought towards the situation and her teaching. Moreover, she also described what her behaviors were towards every circumstance. In addition, the diary itself was written starting from $26^{\text {th }}$ August 2019 until $14^{\text {th }}$ October 2019 with a total of pages of 50.

\section{Semi-structured interview}

Furthermore, to keep the objectivity and credibility of the data, a semi-structured interview was conducted with the in-service teacher who had supervised the participant. The interview was grounded in several question topics, namely perceptions of English language teaching practices, self-adapting strategies towards encountered challenges amid English language teaching, teaching beliefs, the effectiveness of English language teaching practices, perceived language teaching awareness, philosophy of English language teaching, and ultimate goals of English language teaching practices. Conversely, though this was carried out based on the interview protocol and prescribed topics of the question, the interview questions change dynamically depending on the interviewee's responses and unpredicted situations. Therefore, it changes flexibly. To document the interview processes, a smartphone was utilized to record.

\section{Open-ended questionnaire}

An open-ended questionnaire for 30 junior high school students whom the researchers had taught was administered to obtain information about the students' viewpoints of the participant as a pre-service teacher. The student participants consist of 14 males and 16 females with the age range from 14 to 15 years old. According to the school academic record, the average overall English score of the students during their first semester in the second-grade junior high school was 84 in which there were 6 high achievers, 14 middle achievers, and 10 low achievers with Basic English level or elementary level for all types of achievers. During the teaching-learning process, the participant noticed that the students' learning motivation was quite low, proven by the fact that only half of the students were enthusiastic and engaged in the learning process during the teaching-learning activity. To maintain the credibility of this justification, the researcher performed a member checking to another teacher (Bahasa Indonesia Teacher) to confirm the situation and verify the consistency of justification. The result indicated relatively similar justification viz. less excitement, disengaged and demotivation to learn. Given these facts, the generated justification on the students' learning competencies and performances in English has been practically validated.

In practice, the open-ended questionnaires and the interview were utilized as a cross-check tool of what had been done in the class and what had been written in the dairy by the researcher. It 
is considered that an open-ended questionnaire for the students could avoid the nervousness from being asked directly by the participant. The questionnaire was distributed on February $2^{\text {nd }}, 2020$. Therefore, the students were able to express their answers forthrightly.

\section{Data analysis procedure}

Finally, the data were analyzed using narrative analysis which was promoted by Labov \& Waletzky (1997) with the following stages; (a) abstract: a summary of the story (b) orientation: providing a context to orient the reader (c) complicating action: the emergence of a problem through the skeleton, plot or an event, (d) Evaluation: evaluating comment on events, justifying the telling, or giving meaning that the teller gives to an event, (e) result: of resolution of the story and the conflict, (f) Coda: bringing the narrator that was the researcher itself back to the present (Labov \& Waletzky, 1997; De Fina \& Georgakopoulou, 2019; Smith \& Monforte, 2020; De Fina, 2021).

\section{FINDINGS AND DISCUSSION}

\section{At the outset; 'I was confused and I tried to adapt'}

This story began when Tia was assigned to teach the second graders of middle school during teaching practice for 2 months. She was mandated to teach two classes back then. Teaching has been part of her life since she had already been teaching diverse private English courses from the $3^{\text {rd }}$ semester. However, being in a real-life school teaching environment was a novel experience for her. Meeting a new challenge in a new circumstance had raised abundant feelings she sensed during the language teaching activities. At the very first time, she stepped her feet into the classroom all she perceived was confusion. This historical moment was captured in her diary.

"I was feeling confused at the beginning, we don't know what to do, it was our first day at school. I felt confused, like what kind of lesson plan is appropriate, I read some references, I even asked my friend and my senior.” (August 2019)

"When I first started to teach, as usual, I first felt confused about what to do next and what to do after this after that..." (6 September 2019)

In the first week, it was a great challenge for her to apply what she had learned in university to a real situation in the classroom. It is understandable if the participant becomes confused once they begin to create a harmony between theories and practice. In this respect, Foncha (2015) proposed that "it is worthy to note that the relationship between theory and practice appears to be a continuing issue of concern for student teachers" (p.131). Furthermore, she thought of what she had to do to deal with such situations. Fortunately, the confusion emerged along with the adaptive thought. Therefore, she attempted to explore and accustom her feelings and thoughts to the reality that now she is teaching at a real school by focusing on what steps she needed to take before coming to the class. In this phase, she stated that she ought to be well-prepared.

"When I think about my teaching, the most important thing I do that I need to prepare well and remember the step of my teaching because sometimes I am just being indifferent like I know what to do but it ends up like doing whatever I want in class, but then it was not right, the lesson plan must be my guidance so I need to do my lesson plan very well as well." (6 September 2019)

A prospective teacher is usually guided and monitored by the tutor teacher in preparing the lesson plans. In this regard, an interview was conducted with Tia's supervisor teacher to confirm whether she had been preparing the teaching well. 
A Narrative Inquiry of an Indonesian Prospective Teacher's Teaching Experiences: Probing Language Teaching Awareness , Al- Ishlah: Jurnal Pendidikan, 2021, vol. 13 (3), Pages 2114-2131

Zehan Agustia Ainussamsi, Arini Nurul Hidayati, Dede Pertamana, Fuad Abdullah

"According to what I observed, the mastery of the materials of the student-teacher was already excellent, thus probably since she had mastered the materials well so there was no hesitation, already confident.” (5 February 2020)

Obviously, at first, Tia simply focused on herself as she mentioned 'I' quite often and the topic of the passage was all about herself. In this case, she was not merely just conscious about what happened but also sort of analyzing and evaluating herself as she claimed "I need to prepare well... I need to do my lesson plan very well", in short, she was self-focused. When people focus attention on the self, they evaluate their actions in light of relevant standards, goals, and norms (Duval \& Wicklund, 1972; Chang \& Hung, 2018; Aubrey, King, \& Almukhaild, 2020; Ishikawa \& Koshikawa, 2021). According to Whitfield (2007), feeling precedes thinking as the brain favours emotions over what is valued as rationality. Furthermore, when identifying incoming sensory information, the brain also needs to know if the incoming information is good or bad, and this process of characterization of good or bad is facilitated by the mid-brain emotion before one is even consciously aware of the incoming sensory information (Whitfield, 2007; Aubrey, King, \& Almukhaild, 2020). Mid-brain emotion is then assessed and proceeds in microsecond speed by the amygdala, which is a primitive brain structure that has extensive connections to cognitive and motor centres within the brain before it comes to the part of decision making of certain kinds of behavior. With this in mind, before even coming to self-awareness, some processes are occupying the brain which involves the process of feeling and thinking, and the feeling happens to be the first activated sensory before it leads one-self to a behaviour.

To feel, think, and behave are three fundamental components of self-awareness that interfere with one another. Tia's behaviour during language teaching practice was influenced by how she felt and thought about something. In the first three weeks, she still undertook to accustom herself to align her adaptive thoughts and dynamic feelings with the language teaching process and the circumstances. And in this first phase, she endeavoured to understand what had to be done by trying to know the students' characters to align the given circumstance with her teaching. She reveals this emotion in her diary,

"This first-day teaching at class would be my needs analysis. I should've taken it slowly at first and seen my students' background knowledge." (11 August 2019)

"I need to dig more for analysis of their characteristics and how to make them interested in my class. Some of them were very energetic actually, but some were still shy, probably I should spend some more time with my students since this was only our second meeting." (11 August 2019)

Previous research discussed that behavior is a determination to act based on cognitive logic (e.g. Kelly, 1969; Byrne, Crowe, \& Griffin, 1998; Bell, 2005; Duvallet, Walter, Howard \& Hemachandra, 2016; Yan, 2019; Sato, 2021; Chakravarthula, Baucom, Narayanan \& Georgiou, 2021). Those feelings and thoughts are then stored as information, identified, and processed to lead to a certain kind of behaviour (Morin, 2011; Sato, 2021).

\section{Looking around; "Now I feel like knowing what teaching at school is"}

As the days passed by, the feeling of confusion gradually disappeared as Tia continuously embraced herself to adapt, and this was the beginning of her journey as a real English teacher. The period of her first acquaintance with the school was then turned into further exploration. The first two and three weeks were when she finally encountered the starting point. She began to feel the responsibility as a real teacher, and it was far-off from what she expected that there were a lot of 
things that she wanted my students to learn besides English, namely ethics. This urge then somehow moulded her belief in teaching that she wanted her students to learn something and be ethically positive. As a result, the feeling of confusion was replaced by the feeling of joy as she finally felt like she was successfully teaching them something even if it was not English.

"I love teaching the students until they know something that they didn't know before, even one word because I feel like I couldn't leave the class if the students have no idea what's going on or what materials are these, I want my student to gain something from my class, in everything, not only the materials but probably to raise their spirituality the awareness of kindness. In short, I love to guide them to be better students." (5 September 2019)

The moral values she transferred during this period have been sincerely felt by her students, resulting in the emergence of positive vibes. It is evidenced by the open-ended questionnaire revealed by her students.

Student 1: "the lesson was always to be patient, cheerful, friendly, makes somebody feels comfortable..."

Student 2: "yeah, that we have to respect everyone"

Student 3: "yes, so we have to be always kind, to be patient, and to always pay attention while the teacher is explaining something.

Student 4: "yes I did find something to learn, like we have to be polite when we want to answer a question." (Questionnaire, 10 February 2020)

(Aas, 2019)argued that the pleasant feeling the student-teacher illustrates about finally having time to make a good adjustment indicates that she feels responsible. The feeling of responsibility was written where Tia stated that she would not leave the class before the students learned something. Furthermore, there was also a belief in me to guide the student to be ethically positive due to what she felt and experienced in the classroom. Moreover, personal experience and experience with school have the potential to influence and shape an individual's beliefs about teaching (Richardson, 1996; Richards, 2020; Pre, 2021). Also, teachers' theories and beliefs represent the myriad store of general knowledge of objects, people, events and their characteristic relationships that teachers have that affects their planning and their reciprocal thoughts and decision, as well as their classroom behaviour (Nisbett and Ross, 1980; Andriani \& Abdullah, 2017; Xue, S., \& Churchill, 2020; Turhan, B., \& Kirkgöz, 2021). It is obvious that during language teaching practice, she had received myriads of information that was being stored in her brain.

When it comes to the thought, at this time, her thought was getting influenced by those feelings. The feeling of joy by encouraging a positive attitude has altered the thought that making a positive environment needs people who spread positivity. Therefore, through this belief, she managed to focus on shaping students' manners to cope with the learning environment as she attempted to upgrade herself.

"When I think about my teaching, the most important thing I do in my classroom is that I have to manage everything, but the important thing first for me was that student's attitude, cause if we can manage their attitude first then the students could themselves towards the learning" (5 September 2019).

".. I have to consider the time allocation, the duration of our class that we have, and it has to be suited with the materials and their competencies and also the assessment that I need." (10 September 2019) 
A Narrative Inquiry of an Indonesian Prospective Teacher's Teaching Experiences: Probing Language Teaching Awareness , Al- Ishlah: Jurnal Pendidikan, 2021, vol. 13 (3), Pages 2114-2131

Zehan Agustia Ainussamsi, Arini Nurul Hidayati, Dede Pertamana, Fuad Abdullah

The excerpt indicates that the self-awareness of the participant's teaching began by evaluating herself and not just merely being conscious, but the cognitive thought and the appraisal were made. There was self-talk, and it happened continuously. According to Morin (2011), selfawareness involves various kinds of cognitive processes such as self-examination and represents different levels of analysis. Moreover, the self-focused resulted from the discrepancy received by the stored information (Silvia \& Duval, 2001; Peercy \& Sharkey, 2020). People will naturally try to act on the perceived cause of their discrepancy (Heider, 1958; Stefan, \& Cheie, 2020; Jiang \& Papi, 2021). "If self is seen as causal, people will change self; if standards are seen as causal, people will change standards" (Silvia \& Duval 2001, p.234).

\section{Another perspective; "I thought teaching language was only how to teach them to speak the intended language, but it was not"}

In the middle of the teaching practice period, the situation was complicated. Although in this phase, the confusion seemed no longer apparent, however, the more she explored, the more she encountered trials. Those issues were more than just related to the language itself, rather with any other pedagogical challenges such as media of teaching, classroom management, classroom activity, and students' behaviour.

"Sometimes it's hard for me to keep the students quiet while I try to tell them about something, also it's very challenging to shape their character" (7 September 2019).

“...the limits of technology makes it more complicated, I mean I am required to be more creative indeed, and it is not an easy thing, to prepare things like flashcards or something, or when I always have to print materials, that is a little exhausting and costly" (7 September 2019).

"There were always some students who just couldn't stop talking while I was explaining the materials. It happened over and over, I was confused about what to do but I don't want to offend anyone, I want my students to feel comfortable with me" (October 2019).

Despite the pedagogical challenges she encountered, she also came to the boredom zone. Moreover, she began to be exhausted and unstable.

"Now I feel a little bit bored with my routine like I guess I need to make something new in my teaching." (7 September 2019)

“...but these days also I feel like I am really drained and exhausted, not as energetic as usual but I tried my best to stay stable while teaching, and I also feel like my students are getting bored with the activity because I always give them worksheets and groups, etc." (8 October 2019)

The students also confirmed that they witnessed when their teacher was not in a good mood regarding this condition.

Student 1: "but bored and lazy when being asked to study in a group..."

Student 2:" boring but fun, but boring, but group work is sometimes fun."

(Questionnaire, 4 February 2020) 
From those excerpts, although Tia was not at her best, she tried not to be drowned by that. Instead, she figured out something to make her teaching better. Baumeister \& Vohs (2003) noted that one major adaptive function of self-awareness is self-regulation, which includes altering one's behaviour, resisting temptation, changing one's mood, selecting a response from various options, and filtering irrelevant information. In the given period, the conscious feeling of boorishness leads her to think about something new in her teaching to vanish the boredom (Rianti, Hidayati, Pertamana, Andriani, \& Abdullah, 2020). In other words, she had regulated herself to respond to her feelings by thinking about something new for a positive outcome. The feeling of hardship in teaching aligned with her thoughts as these two influence one another.

"I never thought that being a teacher would be this hard. Indeed, being a teacher is something complex. I don't only teach, I do everything like literally everything, no I wonder how my supervisor teacher would do such things, probably he just takes it easy. Well, I should take it easy too, shouldn’t I?” (27 September 2019)

In this phase, there was a time where she assumed the complication of being a teacher then compared it to her supervisor teacher to justify herself. As she marked "I wonder how my supervisor teacher would do such things, probably he just took it easy. Hopp, Jakisch, Sturm, Becker, \& Thoma, (2020) suggested that comparison with others motivates individuals to take others' perspectives to gain an objective point of view on them. In this stance, individuals become self-aware and can acquire information about the self (Morin, 2011; Abdullah \& Lulita, 2018; Atagi, \& Sandhofer, 2020; Hu, J., \& Gao, 2021).

\section{Evaluation; "to make them learn is to make a supportive learning environment"}

With all the challenges she encountered, she embarked on resolving this situation. Her language teaching awareness had led her to channel her feelings with the students' feelings, and as a result, he tried to build a fun friendly environment to neutralize the objection she encountered even though it was challenging.

"There were always some students who just couldn't stop talking while I was explaining the materials. It happened over and over, I was confused about what to do but I don't want to offend anyone, I want my students to feel comfortable with me" ( 8 October 2019).

"When I think about my teaching, I realize that the most important thing I do is how to make my student feel comfortable with me and how to make a supportive learning environment, cause if they feel comfortable with me, with the class, they learn better that's what I see so far" (8 October 2019).

"I need to do something because I can't always do the same activity so yeah indeed, I am required, and demanded to be creative, to prepare everything” (8 October 2019).

After realizing the weaknesses and attempting to improve the teaching practice, Tia obtained some positive responses from her students. This can be seen from the following interview result,

Student 1: "So fun, because miss is rarely angry and always entertaining"

Student2: "Feeling good, because she taught patiently, always smile and speak with decent words"

Student3: "feeling comfortable, and she also spoke smoothly."

(Questionnaire, 4 February 2020) 
In this phase, she made a concept of what the student wanted to feel towards her out of her confusion as she said "I was confused what to do but I don't want to offend anyone, I want my student to feel comfortable with me". Gibbons (1983) and Markus (1983) marked that selfawareness also increases accurate access to one's self-concept. Self-awareness also channeled oneself to employ in Theory of Mind (ToM) (Morin, 2011; Wellman, 2018; Astington, 2020), which constitutes a fundamental component of social cognition (Malle, 2005; Quesque, F., \& Rossetti, 2020). ToM represents the ability to attribute mental states such as goals, intentions, beliefs, desires, thoughts, and feelings to others (Gallagher \& Frith, 2003; Yu, Kovelman, \& Wellman, 2021; Zhu, Neubig, \& Bisk, 2021). In this case, self-awareness had driven her to a certain kind of concept of her teaching style that is to make the student comfortable, and how she wanted to make her students feel towards her language teaching.

Along with this phenomenon, her thought continuously developed, her language teaching awareness had altered the thought to focus on herself. In this stance, the objective of her focus was to improve her teaching to encounter the challenges. In short, the awareness is still addressed on the self, not to the environment. As a consequence, she kept trying to improve her pedagogical skill.

"The most important thing I do in my classroom is that I have to be aware and know what to do, especially when the students are not as I expected, so I need to prepare for everything including the backup as well." (29 September 2019)

“...I think my students need something fun, and lately I just realized it's been so long since I gave my students rewards. I guess I should do that again so that my students would feel motivated." ( 19 October 2019)

The supervisor teacher and the students seemed to agree with her attempt to make the supportive fun learning environment. From another interview, the supervisor teacher mentions,

Teacher: "...the mastery of the materials is already good, so automatically we umm easy to improve umm, for instance, the teaching activity, how is it going to be, right? to make it more interesting, so the concern doesn't only to the materials because it is already being mastered that is what I mean, so there came other options to make an interesting class such as, making a group based on the name of the countries, also the clapping hand signs, for me that was quite interesting for the students, especially when there was a reward for the students, and for me, the student-teacher done something like in her teaching practice was good enough." (Interview, 15 February 2020).

Moreover, some of the students also maintained that she had done an exciting performance during teaching practice,

Student 1: "what I felt was that it was more fun because there was a reward"

Student 2: "So much fun, because it is not ordinary learning, studying but with humor too." (Questionnaire, 20 February 2020)

In this case, she desired a positive outcome, as she mentioned: “...so that my students would feel motivated". "Positive outcome expectancy and high rate of progress increase the likelihood of hanging the self as opposed to escaping it" (Morin, 2011, p.812). The belief to promote a positive environment which was constricted by the development of the feelings had delivered her to open the self-regulation and provided various kinds of options of what she was going to do to her language teaching, and as she consistently expected the positive result. Thus, the regulation became the guidance for her to change herself or the standard to adjust to the circumstances. 
On the other hand, when being encountered with boorishness, Tia wrote how she tried to adjust the language teaching activity with the students' emotions. In this phase, she thought to do something but in the end, there was a realization that she could not compel the situation,

"I let my students' mood and emotion flow naturally and with no force or anything, but I still make the class stable and well accordingly, like all the students finished their task and performance even though I know some of them were not really into it. When I first started to teach, I thought about what to do, because I saw that my student did not seem as cheerful as usual, so it was like I needed to do something but then as I tried to, I realized that there is something that we couldn't force." (17 September 2019)

In this case, she considered letting her students express their emotions as her awareness channeled their feelings with hers. By doing so, she avoided crossing their border and did not push them too hard when it came to studying.

Regarding this phenomenon, the reflective mind and the thought has happened until it came up to the situation where she ought to do something to successfully live up again in the classroom. In practice, the most favorite language teaching approach for her is one that can accommodate and integrate what she thought and perceived. In other words, such an approach is anchored in the cognitive and emotional principles of language teaching where mind and feel meet. In addition, teaching strategies and skills are allied closely to attitudes towards oneself and pupils (Tavoosy \& Jelveh, 2019; MacIntyre, Gregersen, \& Mercer, 2020; Yang \& Kuo, 2020; Mauludin, 2021). In other words, she attempted to humanize her students while engaging in English language teaching practices. As an illustration, she was aware of considering her students' self-esteem, curiosity, open-mindedness, respect, and reflection.

\section{Final remarks: “A language teacher's duty is not merely teaching language, rather helping the students to learn"}

Towards the end of the language teaching practicum, Tia contemplated all the circumstances she had passed. And in that contemplation, she acquired her value as an English teacher, the sense of identity which she had never felt before. She began to feel her role and the responsibility as a teacher, and her thought came to the conclusion which emerged her teacher's identity,

"I could feel the responsibility, it's like I have children, and I can't leave my children just like that and I have materials I need to deliver." (8 October 2019)

"I need to manage the class well, that's the important thing, and I need not forget about who I am, that I am a teacher, I need to be their teacher, leader, friend, controller." ( 8 October 2019)

Being aware of the feeling towards a certain situation during language teaching had helped Tia to improve her teaching practice. Likewise, being aware of her thoughts came to the conclusion where she finally had a sense of identity as a teacher. The focus was prominently on the self, with a variety of objections such as on the teaching, preparation, the attitude towards the students, as to reach the desirable standard of learning objectives. Thus, she attempted to repair her language teaching over time. "When self-awareness is high, people self-enhance heightened" (Silvia \& Duval, 2001a). Self-enhance was also influenced by the positive outcome prospect. After all, she attempted to change herself rather than escaping from her responsibility as an English language teacher. The awareness of thought helped her reflect on herself where reflection is widely considered as a critical process in the construction of teacher identity (Korthagen, 2004; Sutherland, Howard, \& 
A Narrative Inquiry of an Indonesian Prospective Teacher's Teaching Experiences: Probing Language Teaching Awareness , Al- Ishlah: Jurnal Pendidikan, 2021, vol. 13 (3), Pages 2114-2131

Zehan Agustia Ainussamsi, Arini Nurul Hidayati, Dede Pertamana, Fuad Abdullah

Markauskaite, 2010). When it comes to her behavior, it was indeed affected by how she felt and thought. Being self-aware of her language teaching helped her rebuild a lively classroom environment. The feeling and thought enable the self to reflect and facilitate smooth navigation in the social environment and thus increases the likelihood of survival (Leary, 2004; Hidayati, Ramalia \& Abdullah, 2021).

\section{Lesson learned; "Today I've just realized what it means to be a real teacher, a good one. It is a serious job, indeed."}

As a result, the processes of language teaching awareness somehow brought her to another point that is realization. Farrell (2012) called this realization as noticing and it is the starting point in language teacher professional development. In an early diary entry she wrote about her beliefs and the value of being a language teacher.

"I realize that teaching is not only about teaching, I just realize and experienced it myself, being a teacher means being a manager, a motivator, an entertainer and an educator, of course, being a teacher also means being an artist, because teaching is an art, we have to teach beautifully and appropriately." (29 September 2019)

Moreover, in another page, Tia also jotted down that it is important to build a studentteacher relationship.

"Now, I am aware and realize that building a relationship and student's confidence is really important, making them comfortable with me but still also they don't forget that I am their teacher is essential and indeed it's not that easy." (29 September 2019)

In this case, as cited in Claessens et al. (2017), a previous study suggested that positive relationships with students, in which high levels of affiliation prevail, are mentioned to be one of the primary reasons for teachers to stay in the profession (O'Connor, 2008; Veldman, van Tartwijk, Brekelmans, \& Wubbels, 2013) and one of the most important sources of enjoyment of, and motivation for, teaching (Hargreaves, 2000; Yundayani, Abdullah, Tandiana \& Sutrisno, 2021; ). Furthermore, "positive teacher-student relationships also have a strong relationship with student motivation and learning (Claessens et.al, 2017, p. 491). On another page of the diary, she also mentioned that motivating and encouraging the student was essential. This realization of the importance of motivating students seems to be fruitful, as cited in Anjomshoa and Sadighi (2015), motivation is a major factor in the successful study of language acquisition. It is considered goaldirected and defined as "the combination of effort plus desire to achieve the goal of learning the language plus favorable attitudes toward learning the language" (Gardner, 1985, p. 10 cited in Xu 2008; Rosmala, Hidayati \& Abdullah, 2021).

"I realize that encouraging and giving motivation to the students is really important so that they feel supported and nothing burdens them, making a fun enjoyable learning situation is the key but still it has to be meaningful." (29 September 2019)

The findings provide information that the process of language teaching awareness development brought her into a deeper meaning by the end of her language teaching practicum, such as having the realization of the pedagogical implication of teaching beliefs and practices where it delivered her to value what is teaching for her and to feel the responsibility of it until it comes to a realization of language teaching practice which further could be channeled as a link into professional development. 


\section{CONCLUSION}

The present study aims at exploring the development of language teaching awareness experienced by a prospective teacher during teaching practicum. The findings outlined that the perceived development of language teaching awareness of the participant encompasses four major themes, viz. the dynamic feeling towards the language teaching practice, the adaptability towards the language teaching activities in certain kinds of circumstances, the ability to adjust to diverse teaching circumstances, the ability to adjust with diverse teaching circumstances, and realization of the pedagogical implication of teaching beliefs and practices.

Pedagogically speaking, this study has shown the insight that language teaching awareness explored through self-awareness promotes self-reflection, self-regulation, and selfevaluation where it enables the participant to gain self-concept and self-consistency in language teaching during its development process. In this case, the language teaching awareness has helped Tia to track down her mind, which is based on the clarification and reflection on her feelings. Moreover, what makes the language teaching awareness successfully grants a positive impact was that she continually expected positive outcomes.

It is admitted that there were several deficiencies to point out in this study. Since the study discussed language teaching awareness and how it developed through time, the process of diary writing could have been extended to spot more significant changes, as a development needs time to process. Moreover, the researchers did not mention whether language teaching awareness is also affected by personality. However, there are possible suggestions for further research to develop this study by having at least one of these following improvements. First, this study could be developed by involving more participants to broaden the perspectives towards language teaching awareness. Inviting more prospective teachers who teach different grades or different schools to compare the results of the language teaching awareness since the circumstances in a different school or different grades might be distinct. Furthermore, the focus of the study can be pointed towards the students to explore whether during the language teaching the students also develop their awareness towards language learning to open insight into the perspective of the learners, examining their beliefs on learning or finding out what sort of motivations which encourage them to learn.

\section{REFERENCES}

Aas, H. K. (2019). Teachers talk on student needs: exploring how teacher beliefs challenge inclusive education in a Norwegian context. International Journal of Inclusive Education, 1-15.

Abdullah, F. and Lulita. (2018). Social actors in an Intercultural Communication classroom: A discursive lens of intercultural education. Indonesian JELT, 13(1), 31-51.

Andriani, A., \& Abdullah, F. (2017). Invigorating the EFL students in acquiring new linguistic knowledge: Language learning through projects. Proceedings of the 4th international language and language teaching conference, Nov 2017, (pp. 1-15). Yogyakarta: English Language Education Study Program, Sanata Dharma University.

Anjomshoa, L., \& Sadighi, F. (2015). The importance of motivation in second language acquisition. International Journal on Studies in English Language and Literature (IJSELL), 3(2), 126-137.

Astington, J. W. (2020). The developmental interdependence of theory of mind and language. In Roots of human sociality (pp. 179-206). London: Routledge.

Atagi, N., \& Sandhofer, C. M. (2020). Early language environments predict aspects of explicit language awareness development. Language Learning, 7O(2), 464-505.

Aubrey, S., King, J., \& Almukhaild, H. (2020). Language learner engagement during speaking tasks: A longitudinal study. RELC Journal, o033688220945418.

Barkhuizen, G., Benson, P., \& Chik, A., (2014). Narrative inquiry in language teaching and learning Research. Pp. 2-3

Baumeister, R. F., \& Vohs, K. D. (2003). Self-regulation and the executive function of the self. In M. R. Leary \& J. P. Tangney (Eds.), Handbook of Self and Identity (pp. 197-217). New York, 
A Narrative Inquiry of an Indonesian Prospective Teacher's Teaching Experiences: Probing Language Teaching Awareness , Al- Ishlah:

Jurnal Pendidikan, 2021, vol. 13 (3), Pages 2114-2131

Zehan Agustia Ainussamsi, Arini Nurul Hidayati, Dede Pertamana, Fuad Abdullah

NY: Guildford Press.

Beaudrie, S., Amezcua, A., \& Loza, S. (2021). Critical language awareness in the heritage language classroom: design, implementation, and evaluation of a curricular intervention. International Multilingual Research Journal, 15(1), 61-81.

Beck, C., \& Kosnik, C. (2006). Innovations in teacher education: A social constructivist approach. Albany: University of New York Press.

Bell, T. R. (2005). Behaviors and attitudes of effective foreign language teachers: Results of a questionnaire study. Foreign Language Annals, 38(2), 259-270.

Boonsuk, Y., Ambele, E. A., \& McKinley, J. (2021). Developing awareness of Global Englishes: Moving away from 'native standards' for Thai university ELT. System, 99, 102511.

Braun, V., \& Clarke, V. (2006). Using thematic analysis in psychology. Qualitative research in psychology, 3(2), 77-101.

Byrne, M. E., Crowe, T. A., \& Griffin, P. S. (1998). Pragmatic language behaviors of adults diagnosed with chronic schizophrenia. Psychological Reports, 83(3), 835-846.

Chakravarthula, S. N., Baucom, B. R., Narayanan, S., \& Georgiou, P. (2021). An analysis of observation length requirements for machine understanding of human behaviors from spoken language. Computer Speech \& Language, 66, 101162.

Chang, H. H., \& Hung, I. W. (2018). Mirror, mirror on the retail wall: Self-focused attention promotes reliance on feelings in consumer decisions. Journal of Marketing Research, 55(4), 586-599.

Caires, S., Almeida, L. and Vieira, D. (2012). Becoming a teacher: student teachers' experiences and perceptions about teaching practice. European Journal of Teacher Education, 35(2), pp.163178.

Claessens, L. C., van Tartwijk, J., van der Want, A. C., Pennings, H. J., Verloop, N., den Brok, P. J., \& Wubbels, T. (2017). Positive teacher-student relationships go beyond the classroom, problematic ones stay inside. The Journal of Educational Research, 110(5), 478-493

Creswell, J. W. (2012). Educational research: Planning, conducting, and evaluating quantitative and qualitative research (4th ed.). Boston: Pearson.

De Fina, A., \& Georgakopoulou, A. (2019). The handbook of narrative analysis. New Jersey: John Wiley \& Sons.

De Fina, A. (2021). Doing narrative analysis from a narratives-as-practices perspective. Narrative Inquiry, 31(1), 49-71.

Duval, T. S., \& Wicklund, R. A. (1972). A theory of objective self-awareness. New York: Academic Press.

Duval, T. S., \& Lalwani, N. (1999). Objective self-awareness and causal attributions for selfstandard discrepancies: Changing self or changing standards of correctness. Personality and Social Psychology Bulletin, 25(10), 1220-1229.

Duvallet, F., Walter, M. R., Howard, T., Hemachandra, S., Oh, J., Teller, S., ... \& Stentz, A. (2016). Inferring maps and behaviors from natural language instructions. In Experimental Robotics (pp. 373-388). Springer, Cham.

Farrell, T. S. (2013). Teacher self-awareness through journal writing. Reflective Practice, 14(4), 465-471.

Flavian, H. (2016). Towards teaching and beyond: Strengthening education by understanding students' self-awareness development. Power and Education, 8(1), 88-100.

Foncha, J. W., Abongdia, J. F. A., \& Adu, E. O. (2015). Challenges encountered by student teachers in teaching the English language during teaching practice in East London, South Africa. International Journal of Educational Sciences, 9(2), 127-134.

Gallagher, H. L., \& Frith, C. D. (2003). Functional imaging of theory of mind. Trends in Cognitive Science, $7(2), 77-83$.

Gashi, L. (2021). Intercultural Awareness Through English Language Teaching: The Case of Kosovo. Interchange, 1-19.

Gebhard, J. G., \& Oprandy, R. (1999). Language Teaching Awareness (first; J. C. Richard, ed.).Retrieved https://books google.coid/books?hl=id\&ls=\&id=uWGDEblbmMC\& fnd\&pg=PRg\&dq=lan guace esc $=\mathrm{y} \# \mathrm{v}=$ onepage \&q=language teaching awareness\&f=false

Gibbons, F. X. (1978). Sexual standards and reactions to pornography: Enhancing behavioral 
consistency through self-focused attention. Journal of Personality and Social Psychology, 36(9), 976-987.

Gibbons, F. X. (1983). Self-attention and self-report: The "veridicality" hypothesis. Journal of Personality, 51(3), 517-542.

Hanipah, H. (2004). Learning to be reflective: From theory to practices Malaysia experiences.

Han, I., Shin, W. S., \& Ko, Y. (2017). The effect of student teaching experience and teacher beliefs on pre-service teachers' self-efficacy and intention to use technology in teaching. Teachers and Teaching, 23(7), 829-842.

Heeralal, P. J. H. (2014). Mentoring needs of pre-service teachers during teaching practice. A case study at a South African university. Journal of Educational and Social Research, 4(1), 511.

Heider, F. (1958). The psychology of interpersonal relations. New York: John Wiley.

Hidayati, A. N., Ramalia, T., \& Abdullah, F. (2021). Leveraging Skype-based webinars as an English language learning platform. AL-ISHLAH: Jurnal Pendidikan, 13(1), 10-20.

Hopp, H., Jakisch, J., Sturm, S., Becker, C., \& Thoma, D. (2020). Integrating multilingualism into the early foreign language classroom: Empirical and teaching perspectives. International Multilingual Research Journal, 14(2), 146-162.

$\mathrm{Hu}, \mathrm{J} .$, \& Gao, X. (2021). Understanding subject teachers' language-related pedagogical practices in content and language integrated learning classrooms. Language awareness, 30(1), 42-61.

Ishikawa, H., \& Koshikawa, F. (2021). Self-Reported Attention Control Skills Moderate the Effect of Self-Focused Attention on Depression. Sage Open, 11(2), 21582440211027965.

Janssens, K. A. M., Bos, E. H., Rosmalen, J. G. M., Wichers, M. C., \& Riese, H. (2018).qualitative approach to guide choices for designing a diary study. BMC Medical Research Methodology, 18(1), 1-12. https://doi.org/10.1186/s12874-018-0579-6

Kasanda CD. (1995). Teaching practice at the University of Namibia: Views from student teachers. Zimbabwe.

Jiang, C., \& Papi, M. (2021). The motivation-anxiety interface in language learning: A regulatory focus perspective. International Journal of Applied Linguistics.

Kelly, G. A. (1969b).Man's construction of his alternatives. In B. Maher (Ed.), Clinical psychology and personality: The selected papers of George Kelly (pp. 66-93). New York: Wiley. (Reprinted from The assessment of human motives (pp. 33-64), G. Lindzey, Ed., 1958, Rinehart)

Kiggundu, E. M., \& Nayimuli, S. T. (2009). Teaching practice: a make or break phase for student teachers. South African Journal of education, 29(3).

Kim, J. H. (2016). Narrative data analysis and interpretation: Flirting with data. Understanding Narrative Inquiry, edited by $\mathrm{J}$ Kim, 185-224.

Korthagen, F. A. (2004). In search of the essence of a good teacher: Towards a more holistic approach in teacher education. Teaching and teacher education, 20(1), 77-97.

Labov, William, \& Waletzky, J. (1967). Narrative analysis.

Labov, William, \& Waletzky, J. (1997). Narrative analysis: Oral versions of personal experience. Journal of Narrative \& Life History, 1(1-4), 3-38.https://doi.org/10.1075/jnlh.7.02nar

Leary, M. R. (2004). The Curse of the Self: Self-Awareness, Egoism, and the Quality of Human Life. New York: Oxford University Press.

Leat, D. J. (1993). Competence, teaching, thinking, and feeling. Oxford Review of Education, 19(4), 499-510.

Lewis, L. (2021). Finding the stories: a novice qualitative researcher learns to analyze narrative inquiry data. Nurse researcher, 29(2).

Ma'arif, A. S., Abdullah, F., Fatimah, A. S., \& Hidayati, A. N. (2021). Portfolio-Based Assessment in English Language Learning: Highlighting the Students' Perceptions. J-SHMIC: Journal of English for Academic, 8(1), 1-11.

Maila, M. W., \& Pitsoe, V. J. (2014). Teaching Practice as Communities of Inquiry. Journal of Social Sciences, 41(1), 99-106.

Malle, B. F. (2005). Folk theory of mind: Conceptual foundations of human social cognition. In R. Hassin, J. S.

MacIntyre, P. D., Gregersen, T., \& Mercer, S. (2020). Language teachers' coping strategies during the Covid-19 conversion to online teaching: Correlations with stress, wellbeing, and negative emotions. System, 94, 102352. 
A Narrative Inquiry of an Indonesian Prospective Teacher's Teaching Experiences: Probing Language Teaching Awareness , Al- Ishlah:

Jurnal Pendidikan, 2021, vol. 13 (3), Pages 2114-2131

Zehan Agustia Ainussamsi, Arini Nurul Hidayati, Dede Pertamana, Fuad Abdullah

Mauludin, L. A. (2021). Students' Perceptions of the Most and the Least Motivating Teaching Strategies in ESP Classes. Iranian Journal of Language Teaching Research, 9(1), 139-157.

McNeil, L. (2020). Implementing digital game-enhanced pedagogy: Supportive and impeding language awareness and discourse participation phenomena. ReCALL, 32(1), 106-124.

Mead, G. H. (1934). Mind, Self, and Society. Chicago: University of Chicago Press.

Markus, H. (1983). Self-knowledge: An expanded view. Journal of Personality, 51(3), 543-565.

Marwa, M., Cahyono, B. Y., Latief, M. A., \& Prayogo, J. A. (2021). Intercultural Topics in the Indonesian English Language Teaching Classroom: Contextualizing Local and Neutral Cultures to Target and Global Cultures. Journal of Intercultural Communication, 21(1), 3445 .

Mitina, L. (1991). Shaping the Teacher's Professional Self-Awareness. Soviet Education, 33(2), pp.33-43.

Morin, A. (2003). Self-awareness review part 2: Changing or escaping the self. Science \& Consciousness Review, 1.

Morin, A. (2011). Self-awareness part 1: Definition, measures, effects, functions, and antecedents. Social and personality psychology compass, 5(10), 807-823.

Ngara, R., Ngwarai, R., \& Ngara, R. (2013). Teaching practice supervision and assessment as a quality assurance tool in teacher training: Perceptions of prospective teachers at Masvingo Teacher Training Colleges.

Ngwaru C 2013. Pre-service student teacher practices in the teaching of English as a Second Language: Experiences, opportunities, and challenges. Greener Journal of Educational Research, 3(7): 310-317.

Nisbett, R. E., \& Ross, L. (1980). Human inference: Strategies and shortcomings of social judgment.

Ozonur, M. (2021). An investigation of prospective teachers' awareness toward environmental issues: An investigation of prospective teachers' awareness. International Journal of Curriculum and Instruction, 13(2), 1845-1856.

Peercy, M. M., \& Sharkey, J. (2020). Self-Study and English language teaching. International Handbook of Self-Study of Teaching and Teacher Education Practices, 823-868.

Perry R 2004. Teaching Practice for Early Childhood. A Guide for Students. From http://www. Routledge.com catalogs. Retrieved on 18 July 2007.

Pieterse, A. L., Lee, M., Ritmeester, A., \& Collins, N. M. (2013). Towards a model of self-awareness development for counseling and psychotherapy training. Counselling Psychology Quarterly, 26(2), 190-207.

Peatfield, K. (2015). An autobiographical narrative inquiry into the experiences of a French immersion teacher journeying towards inclusion.

Pilitsis, V., \& Duncan, R. G. (2012). Changes in belief orientations of preservice teachers and their relation to inquiry activities. Journal of Science Teacher Education, 23(8), 909-936.

Poulou, M. (2007). Student teachers' concerns about teaching practice. European Journal of Teacher Education, 30(1), pp.91-110.

Pre, S. P. Y. (2021). Second language acquisition and shifting identities. In the personal, place, and context in pedagogy (pp. 165-185). Palgrave Macmillan, Cham.

Quesque, F., \& Rossetti, Y. (2020). What do theory-of-mind tasks measure? Theory and practice. Perspectives on Psychological Science, 15(2), 384-396.

Rembe, S., Shumba, J., \& Mavuso, M. (2016). Teaching Practice Purpose and Implementation: A Concept Paper. International Journal of Educational Sciences, 13(3), 310-317.

Rianti, A., Hidayati, A. N., Pertamana, D., Andriani, A., \& Abdullah, F. (2020). Profiling an Ideal Teacher: Voices from Indonesian Vocational High School Students.

Richards, H., Conway, C., Roskvist, A., \& Harvey, S. (2013). Foreign language teachers' language proficiency and their language teaching practice. The Language Learning Journal, 41(2), 231246.

Richards, J. C. (2020). Exploring emotions in language teaching. RELC Journal, 0033688220927531.

Richardson, B. and Shupe, M. (2003). The Importance of Teacher Self-Awareness in Working with Students with Emotional and Behavioral Disorders. TEACHING Exceptional Children, 36(2), pp.8-13.

Rosmala, D., Hidayati, A. N., \& Abdullah, F. (2021). Early Language Development of a Child with 
Expressive Language Disorder: A Parents' Narration.J-SHMIC: Journal of English for Academic, 8(1), 86-96.

Sato, M. (2021). Mindsets and language-related problem-solving behaviors during interaction in the classroom. Innovation in Language Learning and Teaching, 1-12.

Scaffidi Abbate, C., Boca, S. and Gendolla, G. (2016). Self-awareness, Perspective-taking, and Egocentrism. Self and Identity, 15(4), pp.371-380.

Sifakis, N. C. (2019). ELF awareness in English language teaching: Principles and processes. Applied Linguistics, 4O(2), 288-306.

Silvia, P. and Duval, T. (2001). Objective Self-Awareness Theory: Recent Progress and Enduring Problems. Personality and Social Psychology Review, 5(3), pp.230-241.

Silvia, P. J., \& Duval, T. S. (2001a). Motivation and Emotion in social contexts: Jack Brehm's diverse influence on contemporary psychological thought. (1935), 1-24. Retrieved from https://pdfs.semanticscholar.org/8395/eo7c6d5c71e7a76bf46b31e64c7d10eocab5.pdf

Silvia, P. J., \& Gendolla, G. H. (2001). On introspection and self-perception: Does self-focused attention enable accurate self-knowledge?. Review of General Psychology, 5(3), 241-269.

Silvia, P., Moore, L. and Nardello, J. (2013). Trying and Quitting: How Self-focused Attention Influences Effort During Difficult and Impossible Tasks. Self and Identity, 13(2), pp.231-242.

Smith, B., \& Monforte, J. (2020). Stories, new materialism, and pluralism: Understanding, practicing and pushing the boundaries of narrative analysis. Methods in Psychology, 2, 100016.

Sonday, A., Ramugondo, E., \& Kathard, H. (2020). Case study and narrative inquiry as merged methodologies: A critical narrative perspective. International Journal of Qualitative Methods, 19, 1609406920937880.

Stefan, C. A., \& Cheie, L. (2020). Self-compassion and social anxiety in late adolescence: Contributions of self-reflection and insight. Self and Identity, 1-13.

Sutherland, L., Howard, S., \& Markauskaite, L. (2010). Professional identity creation: Examining the development of beginning preservice teachers' understanding of their work as teachers. Teaching and teacher education, 26(3), 455-465.

Tavoosy, Y., \& Jelveh, R. (2019). Language teaching strategies and techniques are used to support students learning in a language other than their mother tongue. International Journal of Learning and Teaching, 11(2), 77-88.

Turhan, B., \& Kirkgöz, Y. (2021). A critical and collaborative stance towards retrospective reflection in language teacher education. European Journal of Teacher Education, 1-19.

Wellman, H. M. (2018). Theory of mind: The state of the art. European Journal of Developmental Psychology, 15(6), 728-755.

Whitfield, T. A. (2007). Feelings in design-a neuroevolutionary perspective on process and knowledge. The Design Journal, 10(3), 3-15.

Yan, W. (2019). A study on the motivation of minority college students' language behaviors--A case study of some local colleges. Journal of Qujing Normal University, 38(5), 63.

Yang, Y. F., \& Kuo, N. C. (2020). New teaching strategies from student teachers' pedagogical conceptual change in CALL. System, 90, 102218.

Yu, C. L., Kovelman, I., \& Wellman, H. M. (2021). How bilingualism informs theory of mind development. Child Development Perspectives.

Yundayani, A., Abdullah, F., Tandiana, S. T., \& Sutrisno, B. (2021). Students' cognitive engagement during emergency remote teaching: Evidence from the Indonesian EFL milieu. Journal of Language and Linguistic Studies, 17(1).

Xue, S., \& Churchill, D. (2020). Educational affordances of mobile social media for language teaching and learning: a Chinese teacher's perspective. Computer Assisted Language Learning, 1-30.

$\mathrm{Xu}, \mathrm{X} .(2008)$. Influence of Instrumental Motivation on EFL Learners in China and Its Implication on TEFL Instructional Design.Akmal, S. (2011, March 13). Nasib Bahsa Aceh di tengah euforia nasionalisme Keacehan. Serambi Indonesia, p. 1.

Zhu, H., Neubig, G., \& Bisk, Y. (2021, July). Few-shot Language Coordination by Modeling Theory of Mind. In International Conference on Machine Learning (pp. 12901-12911). PMLR. 